\title{
Intergenerationele sociale daling in Nederland
}

\author{
Lex Thijssen \& Maarten H.J. Wolbers ${ }^{1}$
}

Verschillende studies hebben laten zien dat de Nederlandse samenleving opener is geworden in de afgelopen decennia door een toegenomen kans op opwaartse sociale mobiliteit. Onlangs is echter voor het eerst aangetoond dat de kans op neerwaartse mobiliteit voor de jongste geboortecohorten (van mannen) is gestegen. Ondanks deze recente bevinding heeft het onderzoek naar sociale stratificatie en mobiliteit nog maar weinig aandacht besteed aan het verklaren van sociale daling. Dit artikel tracht in deze leemte te voorzien door drie verschillende theoretische perspectieven ter verklaring van de individuele kans op sociale daling te bestuderen. Daarnaast worden trends in sociale daling onderzocht om te bepalen of de rol van deze verklaringen in de loop van de tijd is veranderd. Om de verklaringskracht van de theoretische perspectieven te toetsen, maken we gebruik van de Familie-enquête Nederlandse Bevolking 2009 ( $N=1.423)$. De empirische resultaten laten allereerst zien dat jongere geboortecohorten vaker neerwaarts mobiel zijn dan oudere cohorten. Hiermee bevestigen we de eerdere bevinding dat sociale daling in Nederland steeds vaker voorkomt. In de tweede plaats is gevonden dat met name het opleidingsniveau en de cognitieve vaardigheden van individuen bescherming bieden tegen neerwaartse mobiliteit. Dit is in overeenstemming met de meritocratische benadering. In de derde plaats tonen de resultaten dat de rol van de verschillende individuele factoren ter verklaring van sociale daling niet is veranderd in de loop van de tijd.

\section{Inleiding en probleemstelling}

In het begin van de $20^{\text {ste }}$ eeuw deed zich in Nederland, net als in andere Westerse landen, een overgang voor van een agrarische naar een (post-)industriële samenleving (Breen, 2004). De arbeidsmarkt moderniseerde, de welvaart onder de bevolking nam toe en mensen kregen meer mogelijkheden zichzelf te ontplooien. Ook in politiek opzicht. Sociaal-democratische idealen konden zich daardoor beter verspreiden en dit gaf ruimte voor een verdere groei van de verzorgingsstaat. Het idee dat sociale herkomst niet langer beslissend mocht zijn voor iemands toekomst werd ook steeds bepalender. Sociale posities dienden niet op basis van sociale herkomst, maar middels eigen inzet en verdiensten te worden verdeeld. Het onderwijs werd daarbij gezien als de manier bij uitstek om dit te creëren (Waslander \& Bosman, 1997). De toegang tot het (hoger) onderwijs werd zodoende verbeterd met maatregelen als de verruiming van het studiebeurzenstelsel in de periode van wederopbouw na de Tweede Wereldoorlog en de invoering van de Mammoetwet in 1968. In combinatie met een florerende economie en een grotere vraag naar goed gekwalificeerd personeel op de arbeidsmarkt kregen meer Nederlanders de mogelijkheid te gaan studeren en zo in sociaal opzicht te stijgen.

In navolging van dit maatschappelijke streven naar meer gelijkheid ontstond binnen de sociale stratificatiesociologie steeds meer belangstelling voor de vraag in hoeverre samenlevingen opener zijn geworden. Zowel in het buitenland (zie o.a. Blau \& Duncan, 1967; Breen, 2004; Erikson \& Goldthorpe, 1992; Lipset \& Bendix, 1959) als in Nederland (zie o.a. De Graaf \& Luijkx, 1995; Ganzeboom \& Luijkx, 2004; ) is veel onderzoek gedaan naar sociale mobiliteitsvraagstukken. Nederlandse studies tonen aan dat sociale herkomst steeds minder invloed heeft gekregen op iemands latere beroepspositie (De Graaf \& Luijkx, 1995; Ganzeboom \& Luijkx, 2004). Ook het directe effect van sociale herkomst op het bereikte opleidingsniveau van een individu is afgenomen. Tot slot is het individuele opleidingsniveau in de loop van de tijd belangrijker geworden voor wat betreft het behalen van een bepaalde beroepspositie (De Graaf \& Luijkx, 1995; Ganzeboom \& Luijkx, 2004). De conclusie lijkt daarmee gerechtvaardigd dat steeds meer mensen (opwaarts) mobiel zijn en de Nederlandse samenleving almaar opener is geworden. 
In hoeverre zal deze openheid zich blijven voortzetten? En waar liggen de grenzen van deze opwaartse sociale mobiliteit? Het succes van de welvaartsstaat heeft tot een massale toestroom naar het hoger onderwijs geleid (Sociaal Cultureel Planbureau [SCP], 2010). Steeds meer mensen benutten de mogelijkheden om langer door te studeren waardoor het opleidingspeil van de Nederlandse (beroeps)bevolking flink is gestegen. Hoewel de vraag naar hooggekwalificeerd personeel ook is toegenomen, heeft de kwalitatieve opwaardering van de beroepenstructuur de enorme onderwijsexpansie niet kunnen bijbenen (Wolbers, De Graaf \& Ultee, 1997). Als gevolg daarvan vindt er diploma-inflatie op de arbeidsmarkt plaats (Wolbers, 1998). Het gevolg ervan is hoogopgeleiden gedwongen worden banen onder hun niveau aan te nemen om niet langdurig werkloos te blijven. Op deze manier treedt een proces van neerwaartse verdringing in werking: hoger opgeleiden verdringen als het ware middelbaar opgeleiden naar lagere banen en middelbaar opgeleiden verdringen op hun beurt laagopgeleiden van de arbeidsmarkt. Wanneer een toenemend aantal personen gedwongen wordt een baan op een lager niveau te accepteren, dan is te veronderstellen dat op den duur steeds meer individuen intergenerationeel zullen dalen ten opzichte van hun ouders (Dronkers, 1994; Waslander \& Bosman, 1997).

Uit recent onderzoek komt inderdaad naar voren dat sociale daling in toenemende mate plaatsvindt. Zo neemt in Groot Brittannië het aantal personen dat opwaarts mobiel is af, terwijl het aantal neerwaarts mobielen toeneemt (Goldthorpe \& Jackson, 2007; Li \& Devine, 2011). Ook in Frankrijk zijn dergelijke processen vastgesteld (Peugny, 2007). In 2010 werd in onderzoek van Tolsma en Wolbers voor het eerst in Nederland een toename in sociale daling geconstateerd (Tolsma \& Wolbers, 2010). Vooral zonen halen steeds vaker een lager opleidings- en beroepsniveau dan hun vader. Vooralsnog gaat deze trend voor vrouwen echter niet op.

Bovenstaande maakt duidelijk dat sociale daling nu en in de toekomst hoogstwaarschijnlijk in toenemende mate zal optreden in Nederland en andere Westerse samenlevingen. Echter, vanwege het prille karakter van deze bevindingen en omdat de focus van het sociale mobiliteitsonderzoek tot op heden voornamelijk lag op opwaartse mobiliteit, zijn nog maar weinig verklaringen getoetst voor sociale daling (voor uitzonderingen, zie Alm (2011) en Peuny (2007)). Het is dus noodzaak om binnen het hedendaagse sociale mobiliteitsonderzoek de aandacht te verleggen. De belangrijkste doelstelling van dit artikel is dan ook om meer inzicht te krijgen in de rol van individuele factoren ter verklaring van sociale daling. Daarnaast zal worden onderzocht in hoeverre de rol van deze factoren door de tijd heen is veranderd. De onderzoeksvragen luiden aldus: Welke individuele factoren liggen ten grondslag aan intergenerationele sociale daling in Nederland? En: In hoeverre is de rol van deze factoren veranderd in de loop van de tijd? Om deze vragen te beantwoorden maken we gebruik van de Familie-enquête Nederlandse Bevolking 2009 (Kraaykamp, Ruiter \& Wolbers, 2009), een retrospectieve gegevensverzameling over de levensloop en leefsituatie van 3.269 individuen.

\section{Theorie en hypothesen}

Hoewel binnen het sociale mobiliteitsonderzoek nog maar weinig aandacht is besteed aan sociale daling, zijn in de literatuur niettemin enkele theoretische benaderingen ontwikkeld die sociale daling op individueel niveau kunnen verklaren. Dit zijn het sociale toevalsperspectief, de meritocratische benadering en de ouderlijke hulpbronnentheorie.

Het sociale toevalsperspectief (Richardson, 1977) veronderstelt dat sociale daling het gevolg is van het noodlot. Mensen die fysieke of mentale gebreken hebben, zullen simpelweg niet in staat zijn de sociale positie van hun ouders te evenaren. Dit geldt bijvoorbeeld voor mensen die kampen met een alcohol- of drugsverslaving, of op jonge leeftijd te maken hebben gehad met gezinsontwrichting, zoals een ouderlijke echtscheiding of het vroegtijdig overlijden van een ouder. Ook mensen met een lichamelijke handicap zullen een grotere kans hebben op sociale daling, omdat zij niet dezelfde handelingen kunnen verrichten als hun ouders. 
Bevindingen van diverse studies bieden reële ondersteuning voor dit perspectief. Allereerst presteren kinderen die een ouderlijke echtscheiding hebben meegemaakt minder goed in het onderwijs en zijn zij op latere leeftijd vaker werkloos (McLanahan \& Sandefur, 1994). Wellicht dat zij daardoor ook kwetsbaarder zijn voor sociale daling. Daarnaast toont Alm (2008) aan dat er een verband bestaat tussen geregistreerd drugsgebruik en intergenerationele sociale daling bij mannen in Zweden. Verder blijken mensen met een mentale aandoening als schizofrenie significant onder te presteren op de arbeidsmarkt en daardoor vaker sociaal te dalen (Timms, 1998). We stellen aldus de volgende hypothesen op: Als individuen op vroegtijdige leeftijd een slechtere (fysieke of mentale) gezondheid hebben, hebben zij een grotere kans op intergenerationele sociale daling (H1). En: Als individuen op vroegtijdige leeftijd met ingrijpende vormen van gezinsontwrichting te maken krijgen, hebben zij een grotere kans op intergenerationele sociale daling $(\mathrm{H} 2)$.

Het tweede perspectief, de meritocratische benadering (Blau \& Duncan, 1967; Miller, 1960; Saunders, 1997), borduurt voort op het idee dat samenlevingen steeds opener zijn geworden. Deze benadering stelt dat posities in de samenleving niet op basis van sociale herkomst, maar via eigen inzet en verdiensten tot stand komen. Als gevolg daarvan nemen werkgevers mensen aan omwille van hun talenten. Naast cognitieve vaardigheden wordt het opleidingsniveau van een individu daarbij als een belangrijke indicator gezien (Arrow, 1973). Te veronderstellen is dat wanneer iemand van hogere sociale herkomst niet de cognitieve vaardigheden of onderwijskwalificaties bezit om zich in de klasse van zijn ouders te handhaven, diegene sociaal zal dalen.

Voor Groot-Brittannië toont Saunders (1997) aan dat iemands cognitieve vaardigheden en inzet belangrijke voorspellers zijn voor zijn of haar kansen op sociale mobiliteit. Verder blijkt uit diverse onderzoeken in Nederland dat het behaalde opleidingsniveau tegenwoordig de belangrijkste predictor is voor het bereiken van een hoge sociale positie (De Graaf \& Luijkx, 1995; Ganzeboom \& Luijkx, 2004). Wanneer we deze bevinding doortrekken naar sociale daling, dan is te veronderstellen dat cognitieve vaardigheden en opleidingsniveau bescherming bieden tegen neerwaartse mobiliteit. We verwachten daarom: Naarmate individuen over meer cognitieve vaardigheden beschikken, hebben zij een kleinere kans op intergenerationele sociale daling (H3). En: Naarmate individuen hoger opgeleid zijn, hebben zij een kleinere kans op intergenerationele sociale daling (H4).

Ouderlijke hulpbronnen staan centraal in de derde verklaring. Deze benadering komt voort uit de culturele reproductietheorie van Bourdieu (1973) en neemt afstand van het meritocratische idee dat sociale herkomst tegenwoordig geen rol meer speelt bij de verdeling van sociale posities. Ouders uit hogere sociale strata trachten namelijk hun positie over te dragen op hun kinderen. Daarbij maken ze gebruik van diverse ouderlijke hulpbronnen. In de eerste plaats beschikken ouders uit hogere sociale klassen over meer economische hulpbronnen. Zij zijn op die manier in staat hun kinderen betere scholing en leervoorzieningen te bieden (Blau \& Duncan, 1967). Kinderen kunnen daardoor langer doorstuderen en vinden vaker een goede baan (Blanden \& Gregg, 2004; De Graaf, De Graaf \& Kraaykamp, 2000). Aldus luidt de hypothese: Naarmate individuen over meer economische hulpbronnen van hun ouders beschikken, hebben zij een kleinere kans op intergenerationele sociale daling (H5).

In de tweede plaats kunnen ouders hun culturele hulpbronnen aan hun kinderen overdragen. Deze hulpbronnen geven individuen meer mogelijkheden te presteren in het onderwijs en beroepsloopbaan. Daarvoor is een aantal redenen te noemen (De Graaf et al., 2000; De Graaf \& Kalmijn, 2001). Allereerst zijn kinderen van ouders met culturele hulpbronnen, wegens hun socialisatie, beter in staat na te denken over abstracte en intellectuele concepten, waardoor ze sneller academische vaardigheden aanleren. Daarnaast hebben dergelijke ouders meer belangstelling voor de schoolprestaties van hun kinderen. Verder worden kinderen die over ouderlijke culturele hulpbronnen beschikken eerder bevoordeeld door leraren op school, of door een baas op het werk, omdat zij beter bekend zijn met de gewoontes en gebruiken van de heersende cultuur in de samenleving. Diverse studies hebben 
aangetoond dat personen met meer culturele hulpbronnen inderdaad beter presteren in het onderwijs en hogere statusbanen bemachtigen (zie bijv. De Graaf et al., 2000; Scherger \& Savage, 2010).

Bovenstaande verklaring kan worden uitgebreid met de statusconsolidatietheorie (Alm, 2011; Richardson, 1977). Deze theorie gaat ervan uit dat ouders, die in het verleden intergenerationeel zijn gestegen zonder dat dit gepaard ging met een gelijktijdige stijging van het behaalde opleidingsniveau, hun kinderen niet genoeg culturele hulpbronnen mee kunnen geven om zich te handhaven in hun sociale klasse. Het gevolg is dat deze kinderen in dezelfde sociale klasse terechtkomen als hun grootouders. De sociale status van eerdere generaties wordt dan als het ware geconsolideerd (Richardson, 1977). Alm (2011) toetste deze hypothese voor Zweden, maar vond geen duidelijk bewijs voor deze theorie. Nochtans kan het bezitten van ouderlijke culturele hulpbronnen goede bescherming bieden tegen sociale daling. In hypothesevorm: Naarmate individuen over meer culturele hulpbronnen van hun ouders beschikken, hebben zij een kleinere kans op intergenerationele sociale daling (H6).

Tot slot is het bezitten van sociaal kapitaal een ouderlijke hulpbron die bescherming kan bieden tegen sociale daling. Kinderen kunnen bij het zoeken naar een baan namelijk gebruikmaken van de contacten in het netwerk van hun ouders (Lin, Ensel \& Vaughn, 1981). Op deze informele wijze hebben personen met veel sociaal kapitaal meer kans op een baan van een gelijke of hogere status dan die van hun ouders. In Nederland blijkt, bijvoorbeeld, dat het verenigingslidmaatschap van ouders een beduidende rol speelt bij de intergenerationele overdracht van beroepsstatus (Van Houten, Gesthuizen \& Wolbers, 2012). Daarnaast kunnen sociale hulpbronnen in het Nederlandse onderwijs een belangrijke rol spelen. Zo is het advies van de leraar erg belangrijk bij de overgang van het basis- naar het voortgezet onderwijs. Goede contacten tussen ouders en docent leiden op deze wijze tot een positiever schooladvies van een kind voor het vervolgonderwijs (Dronkers \& De Graaf, 1995; McNeal, 1999). We verwachten daarom: Naarmate individuen over meer sociale hulpbronnen van hun ouders beschikken, hebben zij een kleinere kans op intergenerationele sociale daling (H7).

Veel studies geven aan dat de Nederlandse samenleving opener is geworden. Er heeft met andere woorden een proces van 'ascription' naar 'achievement' plaatsgevonden (De Graaf \& Luijkx, 1995; Ganzeboom \& Luijkx, 2004). Toegeschreven kenmerken als sociale herkomst hebben in de loop van de tijd aan belang ingeboet, terwijl verworven eigenschappen als opleiding belangrijker zijn geworden in het statusverwervingsproces (Blau \& Duncan, 1967). Enerzijds heeft de opwaardering van de beroepenstructuur ervoor gezorgd dat laag- en ongeschoolde arbeid grotendeels is vervangen door technologische geavanceerde(re) beroepen. Hierdoor is op de arbeidsmarkt een grotere vraag ontstaan naar werknemers met een hoog niveau van kennis en vaardigheden. Anderzijds is het maatschappelijke klimaat zodanig veranderd dat het tegenwoordig niet meer wordt geaccepteerd dat mensen worden beoordeeld op basis van sociale herkomst (Parsons, 1951). Bovendien heeft de Nederlandse overheid met verschillende beleidsmaatregelen getracht de invloed van het sociaal milieu op maatschappelijke kansen te beperken (Dronkers \& De Graaf, 1995). We verwachten daarom, tot slot, dat ouders hun kinderen in latere geboortecohorten minder hulpbronnen mee kunnen geven ter voorkoming van sociale daling. Gezien het toegenomen belang van onderwijskwalificaties en cognitieve vaardigheden op de moderne arbeidsmarkt zullen deze eigenschappen juist meer bescherming zijn gaan bieden tegen neerwaartse mobiliteit. Hieruit vloeien de laatste hypothesen van dit artikel voort: Individuen die zijn opgegroeid in jongere geboortecohorten hebben minder profijt van ouderlijke economische, culturele en sociale hulpbronnen ter voorkoming van intergenerationele sociale daling dan individuen die zijn geboren in oudere geboortecohorten (H8). En: Individuen die zijn opgegroeid in jongere geboortecohorten hebben meer profijt van hun cognitieve vaardigheden en opleidingsniveau ter voorkoming van intergenerationele sociale daling dan individuen die zijn geboren in oudere geboortecohorten (H9). 


\section{Onderzoeksopzet}

Data

Om deze hypothesen te toetsen gebruiken we gegevens van de Familie-enquête Nederlandse Bevolking 2009 (Kraaykamp et al., 2009). In dit survey worden op retrospectieve wijze vragen voorgelegd aan individuen over hun levensloop en leefsituatie. De doelgroep is de Nederlands sprekende bevolking tussen de 18 en 70 jaar oud. Naast de respondent is (indien mogelijk) zijn of haar partner geïnterviewd. De steekproef is getrokken uit een landelijk representatief registerbestand van huishoudens. De oorspronkelijke steekproef op individueel niveau bestond uit 9.177 personen. Hiervan zijn 6.624 individuen daadwerkelijk benaderd en hebben uiteindelijk 3.269 respondenten deelgenomen aan een mondeling interview. De netto-respons bedraagt daarmee 49,4\%. De mondeling geïnterviewden is daarnaast gevraagd een webenquête (of indien gewenst: een schriftelijke enquête) in te vullen. Het aantal personen dat beide ondervragingen succesvol heeft afgerond is 2.802, wat neerkomt op een uiteindelijke respons van $42,3 \%$.

Voor de empirische analyse is een aantal dataselecties toegepast. De belangrijkste reden daarvoor is het uitschakelen van (verstorende) leeftijdseffecten om zo een zuivere cohortvergelijking bedoeld om trends in sociale daling vast te stellen - mogelijk te maken. Daartoe hebben we alleen respondenten geselecteerd die op het moment van ondervraging minstens 35 jaar oud waren en op die leeftijd betaald werk hadden. Eerder onderzoek heeft namelijk laten zien dat rond 35-jarige leeftijd de beroepsloopbaan van individuen (in termen van beroepshoogte althans) is uitgekristalliseerd (Goldthorpe, 1980; Wolbers, Luijkx \& Ultee, 2011). Het gevolg van deze selecties is dat we een groot aantal respondenten verliezen, met name niet-werkzame vrouwen. Tot slot zijn in de multivariate analyse enkel respondenten meegenomen die op alle onderzochte variabelen een geldige score hebben. Uiteindelijk daalde het aantal respondenten hierdoor van 2.802 naar 1.423 .

\section{Operationalisatie}

\section{Afhankelijke variabele}

Intergenerationele sociale daling is vastgesteld door de beroepsstatus van de respondent te vergelijken met die van de ouders. Gebruik is gemaakt van de International Socio-Economic Index of Occupational Status (ISEI) van Ganzeboom, De Graaf en Treiman (1992). Dit is een schaal die loopt van 16 voor beroepen met de laagste status tot 90 voor beroepen met de hoogste status. De beroepsstatusscore van het beroep van de respondent op 35-jarige leeftijd is daarbij gedeeld door de beroepsstatusscore van de vader (toen de respondent 15 jaar oud was). De belangrijkste reden waarom we voor het beroep van de vader hebben gekozen is dat in de twintigste eeuw nog vooral de man kostwinner in het gezin was. Om vervolgens onderscheid te maken tussen intergenerationeel mobielen en immobielen zijn respondenten op basis van hun score in één van de volgende drie groepen ingedeeld: individuen die lager scoren dan 0,9 worden als sociale dalers geclassificeerd, personen die hoger scoren dan 1,1 als sociale stijgers en, ten slotte, degenen met een score tussen 0,9 en 1,1 als sociaal immobielen.

Tabel 1 geeft het percentage dalers, immobielen en stijgers weer voor vier onderscheiden geboortecohorten. Het percentage dalers blijkt in de loop van de tijd te zijn toegenomen. Voor het cohort 1925-1944 bedraagt dit 28,8\% en voor het meest recente cohort (geboren in de periode 1965-1974) $32,5 \%$. Daarentegen is het aandeel immobielen en stijgers enigszins afgenomen. In het geboortecohort $1925-1944$ is $24,4 \%$ intergenerationeel stabiel en $46,8 \%$ opwaarts mobiel, terwijl in het cohort $1965-1974$ deze percentages zijn gedaald naar respectievelijk $23,3 \%$ en $44,1 \%$

In tabel 1 zijn de resultaten tevens uitgesplitst naar mannen en vrouwen. In overeenstemming met eerdere bevindingen (Tolsma \& Wolbers, 2010) constateren we dat mannen steeds vaker sociaal dalen. In het oudste cohort bedraagt dit percentage $25,4 \%$ en in het jongste $31,0 \%$. Het aandeel immobiele mannen is eveneens (licht) gestegen. Het aandeel opwaarts mobiele mannen is evenwel 
afgenomen. In het geboortecohort 1925-1944 is 49,2\% opwaarts mobiel; in het cohort 1965-1974 42,6\%. De bevindingen voor vrouwen verschillen aanzienlijk van die voor mannen. We zien dat het percentage vrouwen dat sociaal daalt juist kleiner is geworden in de loop van de tijd. In het oudste cohort daalt $43,3 \%$, van de vrouwen in sociaal opzicht; in het jongste nog maar 34,3\%. Het aandeel immobiele vrouwen schommelt rond de $20 \%$. Tot slot blijkt uit tabel 1 dat vrouwen in de loop van de tijd steeds vaker opwaarts mobiel zijn. We observeren een stijging van 36,7\% in geboortecohort 1925-199 naar 45,9\% in cohort 1965-1974. De afwijkende bevindingen voor vrouwen hangen samen met hun sterk gestegen opleidingspeil en, mede als gevolg daarvan, toegenomen arbeidsmarktparticipatie.

Tabel 1. Ontwikkelingen in intergenerationele beroepsmobiliteit naar geboortecohort en geslacht

\begin{tabular}{|c|c|c|c|c|}
\hline \multicolumn{5}{|l|}{ Totaal } \\
\hline Cohort & $\mathrm{N}$ & Dalers & Immobielen & Stijgers \\
\hline 1925-1944 & 156 & $28,8 \%$ & $24,4 \%$ & $46,8 \%$ \\
\hline 1945-1954 & 557 & $30,5 \%$ & $24,8 \%$ & $44,7 \%$ \\
\hline 1955-1964 & 548 & $32,1 \%$ & $22,6 \%$ & $45,3 \%$ \\
\hline $1965-1974$ & 510 & $32,5 \%$ & $23,3 \%$ & $44,1 \%$ \\
\hline Totaal & 1771 & $31,5 \%$ & $23,7 \%$ & $44,1 \%$ \\
\hline \multicolumn{5}{|l|}{ Mannen } \\
\hline Cohort & $\mathrm{N}$ & Dalers & Immobielen & Stijgers \\
\hline 1925-1944 & 126 & $25,4 \%$ & $25,4 \%$ & $49,2 \%$ \\
\hline 1945-1954 & 395 & $26,8 \%$ & $27,6 \%$ & $45,6 \%$ \\
\hline 1955-1964 & 325 & $28,3 \%$ & $22,2 \%$ & $49,5 \%$ \\
\hline $1965-1974$ & 277 & $31,0 \%$ & $26,4 \%$ & $42,6 \%$ \\
\hline Totaal & 1123 & $28,1 \%$ & $25,5 \%$ & $46,4 \%$ \\
\hline \multicolumn{5}{|l|}{ Vrouwen } \\
\hline Cohort & $\mathrm{N}$ & Dalers & Immobielen & Stijgers \\
\hline $1925-1944$ & 30 & $43,3 \%$ & $20,0 \%$ & $36,7 \%$ \\
\hline 1945-1954 & 162 & $39,5 \%$ & $17,9 \%$ & $42,6 \%$ \\
\hline 1955-1964 & 223 & $37,7 \%$ & $23,3 \%$ & $39,0 \%$ \\
\hline $1965-1974$ & 233 & $34,3 \%$ & $19,7 \%$ & $45,9 \%$ \\
\hline Totaal & 648 & $37,2 \%$ & $20,5 \%$ & $42,3 \%$ \\
\hline
\end{tabular}

Bron: Familie-enquête Nederlandse Bevolking 2009 (eigen bewerking)

\section{Onafhankelijke variabelen}

\section{Sociale toevalsperspectief}

De invloed van het sociale toevalsperspectief wordt met behulp van een viertal kenmerken bestudeerd die grotendeels voorafgaan aan het moment van intrede op de arbeidsmarkt. Allereerst bekijken we de invloed van gezondheidsproblemen, die mogelijkerwijs verhinderen dat een persoon zich op een goede manier op de arbeidsmarkt kan ontwikkelen. Als indicator daarvoor gebruiken we een meting van de subjectieve gezondheid op 20-jarige leeftijd van de respondent. Mensen konden op een schaal van 1 (heel slecht) tot en met 5 (heel goed) aangeven hoe gezond zij zich toen voelden. Verschillende studies tonen aan dat de subjectieve meting van gezondheid een goede indicator vormt voor de algehele (zowel lichamelijke als psychische) gezondheid van een persoon (Idler \& Benyamini, 1997; Jylhä, 2009).

Daarnaast kunnen plotselinge negatieve veranderingen in de gezinssituatie op jonge leeftijd invloed hebben op de kans om sociaal te dalen. We bekijken de invloed van een ouderlijke echtscheiding en het vroegtijdig overlijden van minstens één van de ouders. In de vragenlijst is gevraagd of, en zo ja, wanneer (op welke leeftijd) iemand een ouderlijke echtscheiding heeft meegemaakt. De uitkomsten zijn omgecodeerd naar twee verschillende categorieën: individuen die geen ouderlijke echtscheiding hebben meegemaakt voor hun $18^{\mathrm{e}}$ levensjaar en degenen die dat wel hebben ervaren. Daarnaast moesten respondenten aangeven of hun ouders reeds zijn overleden en in welk jaar dit gebeurde. Er is gekozen om 
ook hier een dichotomie te maken die bestaat uit een categorie respondenten die minstens één ouder verloor voor de leeftijd van 18 jaar en een categorie mensen die hun ouder(s) niet voor hun $18^{\mathrm{e}}$ levensjaar kwijtraakte als gevolg van sterfte.

Ten slotte wordt binnen dit perspectief bekeken of slachtofferschap van geweld invloed heeft op neerwaartse mobiliteit. Gebaseerd op de vraag of, en zo ja, op welke leeftijd individuen (voor het eerst) slachtoffer zijn geworden van geweld is onderscheid gemaakt tussen personen die geen slachtoffer zijn geweest voor hun $18^{\mathrm{e}}$ levensjaar en personen die dat wel zijn geweest.

\section{Meritocratisch benadering}

Cognitieve vaardigheden zijn geoperationaliseerd aan de hand van vragen over de lagere schooltijd. Respondenten moesten aangeven hoe goed ze zichzelf toen achtten in rekenen en taal. Daarbij konden ze kiezen uit de antwoorden: zwak, matig, redelijk, goed en heel goed. Vervolgens zijn deze twee vragen samengevoegd tot één schaal (Spearman-Brown coëfficiënt $=0,535$ ). Een lage score (minimum is 1 ) wijst op minder cognitieve vaardigheden en een hoge score (maximum is 5) op meer cognitieve vaardigheden.

Naast cognitieve vaardigheden nemen we het opleidingsniveau van individuen mee in de analyse. Het opleidingsniveau is rechtstreeks gevraagd en omgezet in een intervalvariabele. Hierbij is het aangegeven opleidingsniveau omgezet in het minimum aantal jaren onderwijs dat nodig is om dit niveau te bereiken. De variabele varieert tussen 6 (alleen lager onderwijs voltooid) en 21 (postacademisch onderwijs voltooid) jaren onderwijs.

\section{Ouderlijke hulpbronnentheorie}

In de vragenlijst bestaat geen directe meting van de economische hulpbronnen van de ouders in de jeugd van de respondent. Niettemin is het op indirecte wijze mogelijk hiervan een inschatting te maken. We baseren deze meting op de vraag "Kunt u voor elk van de volgende goederen aangeven of ze bij $u$ thuis in bezit waren toen u ongeveer 15 jaar oud was?". De betreffende goederen waren: een auto, een magnetron, een badkamer met ligbad, een diepvriezer en een afwasmachine. Factoranalyse wijst uit dat deze items naar één dimensie verwijzen. Aansluitend is voor deze set items een Likertschaal geconstrueerd die loopt in de richting van minder (minimumscore 0 ) naar meer ouderlijk economisch kapitaal (maximumscore 1). De Cronbachs alpha bedraagt 0,662 , wat voldoende te noemen is bij vijf items.

De meting van de culturele hulpbronnen van de ouders is gebaseerd op de meer gangbare operationalisatie daarvan in de literatuur (zie bijvoorbeeld De Graaf et al., 2000). Allereerst zijn vragen gesteld over het culturele gedrag van ouders. Respondenten konden aangeven hoe vaak hun ouders klassieke concerten, (culturele of historische) musea en/of theaterstukken bezochten. Naast deze traditionele meting van cultureel kapitaal zijn items opgenomen die verwijzen naar het leesgedrag van de ouders. Het gaat daarbij om vragen over de mate waarin ouders Nederlandse literatuur, detectives, populair wetenschappelijke lectuur en/of buitenlandse literatuur lazen. Tot slot zijn vragen voorgelegd over de mate waarin ouders het lezen van hun kinderen stimuleerden. Respondenten konden aangeven in hoeverre ouders henzelf boeken voorlazen, boeken gaven, boeken aanraadden en/of geïnteresseerd waren in de boeken die zij lazen. Factoranalyse wijst uit dat al deze items naar één dimensie verwijzen. Op basis van deze items is een Likertschaal geconstrueerd met scores die variëren van minder (minimumscore van 1) naar meer cultureel kapitaal (maximumscore van 3). Cronbachs alpha van deze schaal bedraagt 0,876 .

De laatste vorm van ouderlijke hulpbronnen is het sociaal kapitaal van de ouders. Respondenten konden in de vragenlijst aangeven of hun ouders lid waren van een politieke partij of een vrijetijdsorganisatie (bijvoorbeeld een sportvereniging, maar ook een Rotary club of Lions). Daarnaast werd gevraagd of ouders vrijwilligerswerk verrichtten voor een geloofsgemeenschap of op school. De activiteiten waaraan de ouders deelnamen, hebben we bij elkaar opgeteld en tot een schaal ter meting 
van ouderlijke sociale hulpbronnen geconstrueerd (Cronbachs alpha=0,298). Respondenten van wie de ouders aan geen enkele activiteit deelnamen, krijgen de score 0 en degenen met ouders die aan alle onderscheiden activiteiten deelnamen een score van 4 .

\section{Controlevariabelen}

Ook zijn enkele controlevariabelen opgenomen. In de eerste plaats wordt gecontroleerd voor de beroepsstatus van de vader om de invloed van bodem- en plafondeffecten uit te schakelen. In de tweede plaats wordt rekening gehouden met de leeftijd van de vader op het moment dat de respondent 15 jaar oud was. Op deze manier worden ook bij de vader eventuele leeftijdseffecten die samenhangen met hun beroepsloopbaan verdisconteerd. In de derde plaats is gecontroleerd voor geboortecohort (in jaren, gecentreerd rond het gemiddelde van 1957 in de multivariate analyse), etniciteit ( $0=$ =autochtoon, $1=$ allochtoon) en geslacht ( $0=$ vrouw, $1=$ man).

De beschrijvende statistieken van alle onafhankelijke variabelen staan weergegeven in tabel 2 .

Tabel 2. Beschrijvende statistieken van onafhankelijke variabelen ( $N=1.423)$

\begin{tabular}{|c|c|c|c|c|}
\hline Variabele & Minimum & Maximum & Gemiddelde & $\begin{array}{l}\text { Standaard- } \\
\text { afwijking }\end{array}$ \\
\hline Geboortejaar & 1928,00 & 1974,00 & 1957,45 & 9,49 \\
\hline Beroepsstatus vader & 24,00 & 86,00 & 45,10 & 14,33 \\
\hline Leeftijd vader (op 15-jarige leeftijd respondent) & 30,00 & 77,00 & 47,18 & 6,31 \\
\hline Allochtoon & 0,00 & 1,00 & 0,09 & \\
\hline Man & 0,00 & 1,00 & 0,63 & \\
\hline Gezondheid op 20-jarige leeftijd & 3,00 & 5,00 & 4,55 & 0,57 \\
\hline Scheiding van ouders voor 18 jaar & 0,00 & 1,00 & 0,04 & \\
\hline Overlijden ouder voor 18 jaar & 0,00 & 1,00 & 0,06 & \\
\hline Slachtoffer van geweld voor 18 jaar & 0,00 & 1,00 & 0,06 & \\
\hline Cognitieve vaardigheden & 1,00 & 5,00 & 3,55 & 0,84 \\
\hline Opleidingsniveau & 6,00 & 21,00 & 13,08 & 3,39 \\
\hline Ouderlijke economische hulpbronnen & 0,00 & 1,00 & 0,34 & 0,27 \\
\hline Ouderlijke culturele hulpbronnen & 1,00 & 2,79 & 1,57 & 0,36 \\
\hline Ouderlijke sociale hulpbronnen & 0,00 & 4,00 & 1,02 & 0,99 \\
\hline
\end{tabular}

Bron: Familie-enquête Nederlandse Bevolking 2009 (eigen bewerking)

\section{Resultaten}

Om vast te stellen welke individuele factoren ten grondslag liggen aan sociale daling, maken we gebruik van multinomiale logistische regressie-analyse. Deze vorm van regressie-analyse is gekozen, omdat de afhankelijke variabele drie nominale categorieën kent (dalers, immobielen en stijgers). In de getoonde modellen (zie tabel 3) schatten we de kans om intergenerationeel sociaal te dalen versus de kans om intergenerationeel immobiel te zijn. ${ }^{2}$ Er zijn in totaal vijf modellen onderscheiden. In model 1 worden naast de controlevariabelen de variabelen van het sociale toevalsperspectief opgenomen. In model 2 bestuderen we de effecten van cognitieve vaardigheden en het opleidingsniveau. De invloed van de economische, culturele en sociale hulpbronnen van de ouders wordt in model 3 geanalyseerd. In model 4 zijn alle onafhankelijke variabelen uit de modellen 1, 2 en 3 gelijktijdig opgenomen. Tot slot worden in model 5 de interactie-effecten van de verschillende variabelen ter meting van het sociale toevalsperspectief, de meritocratische benadering en de ouderlijke hulpbronnentheorie met geboortejaar onderzocht. Om inzicht te krijgen in het relatieve belang van de verschillende onafhankelijke variabelen, zijn ze gestandaardiseerd tussen 0 en 1. 
De resultaten uit model 1 wijzen uit dat enkel het overlijden van een ouder voor de leeftijd van 18 jaar resulteert in een grotere kans op neerwaartse mobiliteit. $\mathrm{H} 1$ en $\mathrm{H} 2$ vinden dus maar weinig empirische ondersteuning. In model 2 wordt de invloed van de meritocratische benadering geanalyseerd. Uit dit model komt allereerst naar voren dat de kans op sociale daling kleiner is, naarmate individuen over meer cognitieve vaardigheden beschikken. Ook blijkt dat naarmate personen die hoger zijn opgeleid, minder vaak sociaal dalen. Deze bevindingen zijn daarmee in overeenstemming met $\mathrm{H} 3$ en $\mathrm{H} 4$. De ouderlijke hulpbronnentheorie veronderstelt dat individuen een kleinere kans hebben op intergenerationele neerwaartse mobiliteit, naarmate zij over meer ouderlijke economische, culturele en sociale hulpbronnen beschikken. We constateren dat ouderlijke hulpbronnen er inderdaad toe leiden dat individuen een kleinere kans hebben om sociaal te dalen (zie model 3), ook al zijn de effecten marginaal significant. H5, H6 en H7 kunnen we daarmee (voorlopig) bevestigen.

Tabel 3. Resultaten van multinomiale logistische regressie-analyse van intergenerationele sociale mobiliteit: dalers ten opzichte van immobielen $(\mathrm{N}=1.423)$

\begin{tabular}{|c|c|c|c|c|c|}
\hline Variabele & Model 1 & Model 2 & Model 3 & Model 4 & Model 5 \\
\hline & $\mathrm{B}$ & $\mathrm{B}$ & $\mathrm{B}$ & $\mathrm{B}$ & $\mathrm{B}$ \\
\hline Constante & $-0,359$ & 0,256 & $-0,413$ & 0,203 & 0,938 \\
\hline Geboortejaar & $-0,305$ & 0,005 & 0,253 & 0,397 & $-0,704$ \\
\hline Beroepsstatus vader & $2,076 * * *$ & $3,141 * * *$ & $2,671 * * *$ & $3,394 * * *$ & $3,424 * * *$ \\
\hline Leeftijd vader (op 15-jarige leeftijd respondent) & 0,623 & 0,749 & 0,775 & 0,581 & 0,509 \\
\hline Allochtoon & 0,059 & 0,053 & 0,080 & 0,051 & 0,062 \\
\hline Man & $-0,515^{* *}$ & $-0,506 * *$ & $-0,499 * *$ & $-0,496 * *$ & $-0,518 * *$ \\
\hline Gezondheid op 20-jarige leeftijd & $-0,063$ & & & $-0,052$ & $-0,779$ \\
\hline Scheiding van ouders voor 18 jaar & $-0,011$ & & & $-0,220$ & $-0,718$ \\
\hline Overlijden ouder voor 18 jaar & $0,759 *$ & & & 0,573 & $-0,805$ \\
\hline Slachtoffer van geweld voor 18 jaar & 0,484 & & & 0,428 & 0,367 \\
\hline Cognitieve vaardigheden & & $-0,858^{*}$ & & $-0,768 *$ & $-1,471$ \\
\hline Opleidingsniveau & & $-1,706 * * *$ & & $-1,507 * * *$ & $-2,133^{\sim}$ \\
\hline Ouderlijke economische hulpbronnen & & & $-0,564 \sim$ & $-0,494$ & $-0,513$ \\
\hline Ouderlijke culturele hulpbronnen & & & $-0,733^{\sim}$ & $-0,233$ & 0,956 \\
\hline Ouderlijke sociale hulpbronnen & & & $-0,583^{\sim}$ & $-0,523$ & 0,368 \\
\hline Gezondheid op 20-jarige leeftijd * geboortejaar & & & & & 1,168 \\
\hline Scheiding ouders voor 18 jaar * geboortejaar & & & & & 0,637 \\
\hline Overlijden ouder voor 18 jaar * geboortejaar & & & & & 2,392 \\
\hline Slachtoffer geweld voor 18 jaar * geboortejaar & & & & & 0,109 \\
\hline Cognitieve vaardigheden $*$ geboortejaar & & & & & 1,135 \\
\hline Opleidingsniveau * geboortejaar & & & & & 0,963 \\
\hline Ouderlijke economische hulpbronnen * geboortejaar & & & & & $-0,004$ \\
\hline Ouderlijke culturele hulpbronnen * geboortejaar & & & & & $-1,840$ \\
\hline Ouderlijke sociale hulpbronnen * geboortejaar & & & & & $-1,428$ \\
\hline $\mathrm{X}^{2}$ verandering & 541,422 & 693,495 & 565,006 & 714,356 & 724,960 \\
\hline Vrijheidsgraden & 18 & 14 & 16 & 28 & 46 \\
\hline
\end{tabular}

$\sim=0<0,1 ; *=p<0,05 ; * *=p<0,01 ; * * *=p<0,001$ (2-zijdig)

Bron: Familie-enquête Nederlandse Bevolking 2009 (eigen bewerking)

In model 4 worden de variabelen van de drie theoretische perspectieven gezamenlijk geanalyseerd. De resultaten zijn (wederom) voornamelijk in overeenstemming met de meritocratische benadering: het opleidingsniveau en de cognitieve vaardigheden van individuen bieden de belangrijkste bescherming tegen sociale daling. Daarnaast is te zien dat de eerder waargenomen effecten van de ouderlijke hulpbronnen in dit model worden geïnterpreteerd door de predictoren van de meritocratische benadering. Eveneens blijkt dat, onder controle van de overige variabelen, de invloed van het overlijden van een ouder voor het $18^{\mathrm{e}}$ levensjaar op sociale daling (zoals getoond in model 1) verdwijnt. 
Uit model 5 blijkt tot slot dat de in model 4 gevonden effecten niet verschillen tussen geboortecohorten. Geen enkel interactie-effect is significant, waardoor $\mathrm{H} 8$ en $\mathrm{H} 9$ geen ondersteuning vinden in de geanalyseerde gegevens. ${ }^{3}$

We hebben de resultaten ook voor mannen en vrouwen apart bekeken. De bevindingen van deze analyse staan gepresenteerd in de bijlagen 1 en 2. De resultaten bij de mannen laten grotendeels hetzelfde zien als het totaalbeeld (zie bijlage 1). Het grootste effect gaat uit van het opleidingsniveau, gevolgd door de cognitieve vaardigheden (zie de modellen 2 en 4). Verder blijkt dat de rol van de ouderlijke hulpbronnen bij mannen geringer is (zie model 3 ) en er is geen effect van het overlijden van een ouder voor het $18^{\mathrm{e}}$ levensjaar op de kans op sociale daling (zie model 1 ). Voor vrouwen geldt daarentegen dat deze ingrijpende gebeurtenis in de jeugd juist de enige factor is die bepalend is voor de kans op neerwaartse mobiliteit. Vrouwen die in hun jeugdjaren een ouder door sterfte hebben verloren, krijgen vaker te maken met sociale daling (zie de modellen 1 en 4). Bovendien is dit effect in de loop van de tijd toegenomen, getuige de significante interactieterm tussen deze variabele en geboortecohort in model 5 .

\section{Conclusie en discussie}

In de jaren negentig van de vorige eeuw voorspelden enkele sociologen al dat sociale daling zich in toenemende mate zou voordoen in Nederland en andere westerse samenlevingen (Dronkers, 1994; Waslander \& Bosman, 1997). Een belangrijke aanwijzing daarvoor vormde de bevinding dat de beroepenstructuur de instroom van hoger opgeleiden op de arbeidsmarkt niet langer kon bijbenen. Als gevolg van diploma-inflatie en verdringing zouden, op langere termijn, meer individuen gedwongen worden een lagere positie op de maatschappelijke ladder in te nemen dan hun ouders. Recentelijk lijken studies in zowel binnen- (Tolsma \& Wolbers, 2010) als buitenland (Goldthorpe \& Jackson, 2007; Li \& Devine, 2011; Peugny, 2007) bevestiging te hebben gevonden voor deze verwachting: het aantal mensen dat sociaal daalt, is in recente geboortecohorten toegenomen. Een belangrijke vraag die vervolgens rijst is wie de grootste kans op sociale daling heeft en wat de verklaring daarvoor is. In dit artikel hebben we daarom getracht meer inzicht te verkrijgen in de (veranderende) rol van individuele factoren ter verklaring van intergenerationele sociale daling in Nederland.

We hebben drie theoretische perspectieven gebruikt om de kans op sociale daling bij individuen te verklaren: het sociale toevalsperspectief, de meritocratische benadering en de ouderlijke hulpbronnentheorie. Het eerste perspectief voorspelt dat sociale daling het gevolg is van het noodlot. Gezondheidsproblemen of gezinsontwrichting in de jeugd zouden ertoe leiden dat individuen op latere leeftijd een lagere sociale positie innemen dan hun ouders. Uit de twee andere theoretische perspectieven vloeien tegenstrijdige verwachtingen voort: waar neerwaartse mobiliteit volgens de meritocratische benadering het resultaat is van selectie op (een gebrek aan) eigen inzet en verdiensten ('achievement'), stelt de ouderlijke hulpbronnentheorie evenwel dat sociale herkomst ('ascription') nog steeds een aanzienlijke invloed heeft op iemands latere beroepspositie en, zo ook, of iemand sociaal daalt.

De empirische resultaten leveren weinig ondersteuning voor het sociale toevalsperspectief. Alleen het overlijden van een ouder in de jeugdjaren heeft een effect: individuen (met name vrouwen) die voor het $18^{\mathrm{e}}$ levensjaar minstens één ouder als gevolg van sterfte zijn kwijtgeraakt, hebben een grotere kans op sociale daling. Het feit dat slechts geringe steun is gevonden voor dit perspectief, kan te maken hebben met de mogelijkheid dat de meer extreme gevallen buiten het steekproefkader zijn gevallen of een hoge mate van non-respons kennen. De gevonden resultaten vormen zo wellicht een onderschatting van de werkelijke rol van het sociale toevalsperspectief.

Ook de ouderlijke hulpbronnentheorie wordt nauwelijks bevestigd. Er is weliswaar een invloed van de ouderlijke hulpbronnen gevonden in de analyse, maar de effecten van de economische, culturele 
en sociale hulpbronnen van de ouders verdwijnen zodra rekening wordt gehouden met de invloed van andere, samenhangende individuele kenmerken.

De meritocratische benadering bezit aanmerkelijk meer verklaringskracht. Naarmate individuen (vooral mannen) een hoger opleidingsniveau hebben en over meer cognitieve vaardigheden beschikken, hebben zij een kleinere kans op sociale daling. Dit is in grote lijnen in overeenstemming met de eerdere studies van Alm (2011) voor Zweden en Peugny (2007) voor Frankrijk. De meritocratische benadering heeft echter niet aan invloed gewonnen in de loop van de tijd. Ondanks dat de Nederlandse samenleving steeds opener is geworden en toegeschreven kenmerken als opleiding belangrijker zijn geworden bij het verkrijgen van een maatschappelijke positie dan verworven kenmerken als sociale herkomst (De Graaf \& Luijkx, 1995), is de rol van opleidingsniveau en cognitieve vaardigheden bij het afwenden van sociale daling niet toegenomen.

De voornaamste conclusie van dit artikel is dus dat sociale daling vooral het gevolg is van het meritocratische principe van selectie op eigen inzet en verdiensten. Nochtans dienen we enige voorzichtigheid te betrachten bij deze conclusie. Het is alsnog mogelijk dat kinderen uit hogere sociale klassen het gevaar van sociale daling weten af te wenden, omdat zij met een voorsprong het (middelbaar) onderwijs instromen (Kloosterman et al, 2011). Wel laten de resultaten duidelijk zien dat, ondanks diploma-inflatie en verdringing op de arbeidsmarkt, individuele investeringen in het onderwijs lonend blijven: ze voorkomen immers dat personen sociaal dalen. Met andere woorden: diploma's zijn niet zozeer van absolute, maar vooral van relatieve waarde op de arbeidsmarkt (Wolbers, 1998). Een andere implicatie van de bevindingen in dit artikel is dat het ontstaan van een homogene onderlaag van laagopgeleiden aannemelijker is geworden (Gesthuizen \& Kraaykamp, 2002). Doordat getalenteerde leden uit de lagere sociale klassen hebben geprofiteerd van de onderwijsexpansie, zijn de achterblijvers uit deze sociale strata, inclusief de sociale dalers, degenen met de minste cognitieve vaardigheden (en een laag opleidingsniveau). De mogelijke consequentie van deze ontwikkeling is dat juist deze kwetsbare groep, maar ook daaropvolgende generaties, in steeds meer gemarginaliseerde posities terecht zullen komen met allerlei samenhangende sociale problemen van dien (Gallie, Paugam \& Jacobs, 2003).

Hoewel we met dit artikel enkele nieuwe inzichten hebben verschaft als het gaat om het verklaren van intergenerationele sociale daling onder individuen, verdienen enkele andere aspecten meer aandacht in toekomstig onderzoek. Allereerst hebben we ons hoofdzakelijk gericht op individuele verklaringen van neerwaartse mobiliteit. Desondanks kunnen structurele verklaringen, zoals de invloed van conjuncturele schommelingen in de economie, nog verder worden belicht. Daarnaast ontbreekt landenvergelijkend onderzoek naar sociale daling, ook al is nu voor enkele landen bekend dat het een verschijnsel is dat (in belang) toeneemt. Het opzetten van een landenvergelijkende studie is dus wenselijk. Tot slot hebben we sociale daling in dit artikel onderzocht als het resultaat van een sociale mobiliteitsproces dat zich over twee generaties uitstrekt, terwijl de statusconsolidatietheorie (Richardson, 1977) een driegeneratiesperspectief hanteert. Deze theorie stelt dat ouders, die in het verleden intergenerationeel zijn gestegen zonder dat dit gepaard ging met een gelijktijdige stijging van het behaalde opleidingsniveau, hun kinderen niet genoeg hulpbronnen mee kunnen geven om zich te handhaven in hun sociale klasse. Het gevolg daarvan is dat deze kinderen veelal neerwaarts mobiel zijn en in dezelfde sociale klasse terechtkomen als hun grootouders. Om deze hypothese te toetsen is onderzoek naar drie generaties noodzakelijk. Een eerste aanzet daartoe is in Nederland zeer recentelijk gegeven (Wolbers \& Ultee, 2013).

\section{Noten}

1. Sectie Sociologie, Faculteit der Sociale Wetenschappen, Radboud Universiteit Nijmegen, Postbus 9104,6500 HE Nijmegen. E-mail: m.wolbers@maw.ru.nl.

2. De kans op intergenerationele sociale stijging vergeleken met de kans op immobiliteit is tegelijkertijd geschat in de multinomiale logistische regressie-analyse, maar wordt niet getoond in tabel 3. De resultaten van deze vergelijking zijn op verzoek wel op te vragen bij de auteurs. 
3. Om de robuustheid van de bevindingen na te gaan hebben we enkele additionele modellen geschat. In de eerste plaats hebben we bekeken of we de gevonden resultaten konden repliceren wanneer we niet controleren voor bodem- en plafondeffecten via de beroepstatus van de vader. Alle effecten blijken dan niet meer significant te zijn waardoor we kunnen stellen dat de beroepstatus van de vader meegenomen dient te worden in de analyse om adequate schattingen te krijgen van de verschillende parameters. In de tweede plaats hebben we aparte modellen geschat voor individuen met een vader die een hoge-, midden- of lage statusbaan had (de eerste en laatste groep is bepaald aan de hand van één standaardafwijking boven, respectievelijk onder het gemiddelde) om te bestuderen of de effecten tussen deze herkomstgroepen verschillen. Deze resultaten wijken weinig af van hier gepresenteerde bevindingen. Het opleidingsniveau blijft de belangrijkste predictor. Tot slot hebben we onze resultaten proberen te repliceren door in plaats van beroepsstatus (ISEI) andere maten voor beroepshoogte te gebruiken om sociale daling te operationaliseren: het EGP sociale klassenschema (Erikson, Goldthorpe \& Portocarero, 1979) en de Ultee en Sixma beroepsprestigeschaal (Sixma \& Ultee, 1983). Ook dan blijven de hier gepresenteerde resultaten overeind: het opleidingsniveau is nog steeds de belangrijkste predictor. De effecten van cognitieve vaardigheden blijken overigens wel minder sterk geworden. Verder is het effect van slachtofferschap van geweld in de modellen gebaseerd op het sociale klassenschema significant.

\section{Literatuur}

Alm, S. (2008). Social nedatrorlighet mellan generationer - en provning av tre perspective. Stockholm: Institutet for Framtidsstudier, arbetsrapportserien.

Alm, S. (2011). Downward mobility across generations: The role of parental mobility and education. Sociological Research Online, 16, 1-14.

Arrow, K. (1973). Higher education as a filter. Journal of Public economics, 2, 193-216.

Blanden, J., \& Gregg, P. (2004). Family income and educational attainment: A review of approaches and evidence for Britain. Oxford Review of Economic Policy, 20, 245-263.

Blau, P. \& Duncan, D. (1967). The American occupational structure. New York: Wiley.

Bourdieu, P. (1973). Cultural reproduction and social reproduction. In R. Brown (red.), Knowledge, education and social change (pp. 71-112). London: Tavistock.

Breen, R. (2004) (red.). Social mobility in Europe. Oxford: Oxford University Press.

De Graaf, P.M. \& Kalmijn, M. (2001). Trends in the intergenerational transmission of cultural and economic status. Acta Sociologica, 44, 51-66.

De Graaf, P.M. \& Luijkx, R. (1995). Paden naar succes: geboorte of diploma's? In J. Dronkers \& W.C. Ultee (red.), Verschuivende ongelijkheid in Nederland (pp. 31-45). Assen: Van Gorcum.

De Graaf, N.D., De Graaf, P.M., \& Kraaykamp, G. (2000). Parental cultural capital and educational attainment in the Netherlands: A refinement of the cultural capital perspective. Sociology of education, 73, 92-111.

Dronkers, J. (1994). Onderwijs als voorportaal van sociale daling. De Helling, 7, 26-30.

Dronkers, J. \& De Graaf, P.M. (1995). Ouders en het onderwijs van hun kinderen. In J. Dronkers \& W.C. Ultee (red.), Verschuivende ongelijkheid in Nederland (pp. 31-45). Assen: Van Gorcum.

Erikson, R. \& Goldthorpe, J.H. (1992). The constant flux: A study of class mobility in industrial societies. Oxford: Oxford University Press.

Erikson, R., Goldthorpe, J.H. \& Portocarero, L. (1979). Intergenerational class mobility in three Western European societies. The British Journal of Sociology, 30, 415-441.

Ganzeboom, H. \& Luijkx, R. (2004). Recent trends in occupational class reproduction in the Netherlands 1970-99. In R. Breen (red.), Social mobility in Europe (pp. 345-381). Oxford: Oxford University Press.

Ganzeboom, H.B.G., De Graaf, P.M., \& Treiman, D.J. (1992). A standard international socio-economic index of occupational status. Social Science Research, 21, 1-56.

Gallie, D., Paugam, S. \& Jacobs, S. (2003). Unemployment, poverty and social isolation: Is there a vicious circle of social exclusion? European Societies, 5, 1-32.

Gesthuizen, M. \& Kraaykamp, G. (2002). Ontwikkelingen in verbale capaciteiten van laagopgeleiden in Nederland. De keerzijde van de onderwijsexpansie. Mens \& Maatschappij, 77, 361-380. 
Goldthorpe, J. (1980). Social mobility and class structure in modern Britain. Oxford: Clarendon Press.

Goldthorpe, J.H., \& Jackson, M. (2007). Intergenerational class mobility in contemporary Britain: Political concerns and empirical findings. The British Journal of Sociology, 58, 525-546.

Idler, E.L. \& Benyamini, Y. (1997). Self-rated health and mortality: A review of twenty-seven community studies. Journal of Health and Social Behavior, 38, 21-37.

Jylhä, M. (2009). What is self-rated health and why does it predict mortality? Towards a unified conceptual model. Social Science \& Medicine, 69, 307-316.

Kloosterman, R., Notten, N., Tolsma, J. \& Kraaykamp, G. (2011). The effects of parental reading socialization and early school involvement on children's academic performance: A panel study of primary school pupils in the Netherlands. European Sociological Review, 27, 291-306.

Kraaykamp, G., Ruiter, S., \& Wolbers, M. (2009). Familie-enquête Nederlandse Bevolking 2009 (dataset). Sectie Sociologie, Radboud Universiteit Nijmegen (producent). Den Haag: DANS (distributeur).

Li, Y. \& Devine, F. (2011). Is social mobility really declining? Intergenerational class mobility in Britain in the 1990s and the 2000s. Sociological Research Online, 16, 1-15.

Lin, N., Ensel, W.M., \& Vaughn, J.C. (1981). Social resources and strength of ties: Structural factors in occupational status attainment. American Sociological Review, 46, 393-405.

Lipset, S.E. \& Bendix, R. (1959). Social mobility in industrial society. Berkeley: University of California Press.

McLanahan, S., \& Sandefur, G. (1994). Growing up with a single parent; What hurts, what helps. Cambridge, MA: Harvard University Press.

McLean, R.B. (1999). Parental involvement as social capital: Differential effectiveness on science achievement, truancy, and dropping out. Social Forces, 78, 117-144.

Miller, S.M. (1960). Comparative social mobility. Current Sociology, 9, 1-80.

Parson, T. (1951). The social system. Glencoe: Free Press.

Peugny, C. (2007). La mobilité sociale descendante. L'épreuve du déclassement. [Downward social mobility. The experience of social demotion]. Verkregen van: http://www.sciencespo.fr/osc/sites/sciencespo.fr.osc/files/These_peugny_0.pdf.

Richardson, C.J. (1977). The problem of downward mobility. The British Journal of Sociology, 28, 303-320.

Saunders, P. (1997). Social mobility in Britain: An empirical evaluation of two competing explanations. Sociology, 31, 261-288.

Scherger, S. \& Savage, M. (2010). Cultural transmission, educational attainment and social mobility. The Sociological Review, 58, 406-428.

Sixma, H. \& Ultee, W.C. (1983). Een beroepsprestigeschaal voor Nederland in de jaren tachtig. Mens \& Maatschappij, 58, 360-382.

Sociaal en Cultureel Planbureau. (2010). Wisseling van de macht: generaties in Nederland. Den Haag: SCP.

Timms, D. (1998). Gender, social mobility and psychiatric diagnoses. Social Sciences and Medicine, 46, 1235-1247.

Tolsma, J. \& Wolbers, M.H.J. (2010). Naar een open samenleving? Recente ontwikkelingen in sociale stijging en daling in Nederland. Den Haag: Raad voor Maatschappelijke Ontwikkeling.

Van Houten, J.M.A., Gesthuizen, M. \& Wolbers, M.H.J. (2012). Statusverwerving en de rol van verenigingslidmaatschap als nieuwe compenserende strategie. Mens \& Maatschappij, 87, 125-149.

Waslander, S. \& Bosman, R. (1997). Sociale daling en onderwijs. Beleid \& Maatschappij, 24, 74-84.

Wolbers, M.H.J. (1998). Diploma-inflatie en verdringing op de arbeidsmarkt: Een studie naar ontwikkelingen en opbrengsten van diploma's in Nederland. Amsterdam: Thesis.

Wolbers, M.H.J., De Graaf, P. \& Ultee, W.C. (1997). Ontwikkelingen in de opbrengsten van diploma's op de arbeidsmarkt: structurele veranderingen en veranderde samenhang? Mens \& Maatschappij, 72, 263-283. 
Wolbers, M.H.J., Luijkx, R., \& Ultee,W.C. (2011). Educational attainment, occupational achievement, career peaks: The Netherlands in the second part of the $20^{\text {th }}$ century. European Societies, $13,425-$ 450.

Wolbers, M.H.J. \& Ultee, W.C. (2013). Driegeneraties- en tweeoudersvragen over het opleidingsniveau van mannen en vrouwen in Nederland. Mens \& Maatschappij, 88, 276-299. 
Bijlage 1. Resultaten van multinomiale logistische regressie-analyse van intergenerationele sociale mobiliteit: dalers ten opzichte van immobielen, mannen $(\mathrm{N}=902)$

\begin{tabular}{|c|c|c|c|c|c|}
\hline Variabele & Model 1 & Model 2 & Model 3 & Model 4 & Model 5 \\
\hline & B & $B$ & B & B & B \\
\hline Constante & $-0,457$ & 0,167 & $-0,562$ & 0,264 & 0,105 \\
\hline Geboortejaar & $-0,155$ & 0,216 & 0,263 & 0,341 & 0,655 \\
\hline Beroepsstatus vader & $1,534 * * *$ & $2,935 * * *$ & $2,147 * * *$ & $3,176 * * *$ & $3,242 * * *$ \\
\hline Leeftijd vader (op 15-jarige leeftijd respondent) & 0,355 & 0,218 & 0,319 & 0,215 & 0,217 \\
\hline Allochtoon & 0,046 & 0,002 & 0,081 & 0,032 & 0,070 \\
\hline Gezondheid op 20-jarige leeftijd & $-0,316$ & & & $-0,192$ & $-0,131$ \\
\hline Scheiding van ouders voor 18 jaar & 0,408 & & & 0,236 & $-1,688$ \\
\hline Overlijden ouder voor 18 jaar & 0,517 & & & 0,229 & 1,043 \\
\hline Slachtoffer van geweld voor 18 jaar & 0,458 & & & 0,418 & 1,011 \\
\hline Cognitieve vaardigheden & & $-0,950^{\sim}$ & & $-0,836^{\sim}$ & $-1,707$ \\
\hline Opleidingsniveau & & $-2,202 * * *$ & & $-2,011 * * *$ & $-1,575$ \\
\hline Ouderlijke economische hulpbronnen & & & $-0,354$ & $-0,268$ & $-0,072$ \\
\hline Ouderlijke culturele hulpbronnen & & & $-0,984^{\sim}$ & $-0,401$ & 0,426 \\
\hline Ouderlijke sociale hulpbronnen & & & $-0,425$ & $-0,346$ & $-0,062$ \\
\hline Gezondheid op 20-jarige leeftijd * geboortejaar & & & & & $-0,036$ \\
\hline Scheiding ouders voor 18 jaar * geboortejaar & & & & & 2,478 \\
\hline Overlijden ouder voor 18 jaar * geboortejaar & & & & & $-1,474$ \\
\hline Slachtoffer geweld voor 18 jaar * geboortejaar & & & & & $-0,856$ \\
\hline Cognitieve vaardigheden $*$ geboortejaar & & & & & 1,243 \\
\hline Opleidingsniveau * geboortejaar & & & & & $-0,757$ \\
\hline Ouderlijke economische hulpbronnen * geboortejaar & & & & & $-0,211$ \\
\hline Ouderlijke culturele hulpbronnen * geboortejaar & & & & & $-1,370$ \\
\hline Ouderlijke sociale hulpbronnen * geboortejaar & & & & & $-0,502$ \\
\hline $\mathrm{X}^{2}$ verandering & 330,795 & 450,027 & 344,722 & 464,366 & 477,519 \\
\hline Vrijheidsgraden & 18 & 12 & 14 & 26 & 44 \\
\hline
\end{tabular}

$\sim=p<0,1 ;{ }^{*}=p<0,05 ;{ }^{* *}=p<0,01 ;{ }^{* * *}=p<0,001$ (2-zijdig)

Bron: Familie-enquête Nederlandse Bevolking 2009 (eigen bewerking) 
Bijlage 2. Resultaten van multinomiale logistische regressie-analyse van intergenerationele sociale mobiliteit: dalers ten opzichte van immobielen, vrouwen $(\mathrm{N}=521)$

\begin{tabular}{|c|c|c|c|c|c|}
\hline Variabele & Model 1 & Model 2 & Model 3 & Model 4 & Model 5 \\
\hline & B & B & B & $B$ & B \\
\hline Constante & $-1,013$ & $-0,242$ & $-0,930$ & $-0,814$ & 1,830 \\
\hline Geboortejaar & $-0,494$ & $-0,506$ & 0,219 & 0,467 & $-3,411$ \\
\hline Beroepsstatus vader & $3,101 * * *$ & $3,610 * * *$ & $3,643 * * *$ & $3,897 * * *$ & $4,175^{* * *}$ \\
\hline Leeftijd vader (op 15-jarige leeftijd respondent) & 0,665 & 1,204 & 1,197 & 0,747 & 0,613 \\
\hline Allochtoon & 0,275 & 0,198 & 0,128 & 0,235 & 0,195 \\
\hline Gezondheid op 20-jarige leeftijd & 0,392 & & & 0,343 & $-1,775$ \\
\hline Scheiding van ouders voor 18 jaar & $-0,502$ & & & $-0,777$ & $-1,117$ \\
\hline Overlijden ouder voor 18 jaar & $1,262^{\sim}$ & & & $1,144^{\sim}$ & $-4,582^{\sim}$ \\
\hline Slachtoffer van geweld voor 18 jaar & 0,632 & & & 0,581 & $-1,012$ \\
\hline Cognitieve vaardigheden & & $-0,748$ & & $-0,555$ & $-1,094$ \\
\hline Opleidingsniveau & & $-0,773$ & & $-0,506$ & $-2,998$ \\
\hline Ouderlijke economische hulpbronnen & & & $-0,906$ & $-0,931$ & $-2,759$ \\
\hline Ouderlijke culturele hulpbronnen & & & $-0,203$ & $-0,043$ & 2,367 \\
\hline Ouderlijke sociale hulpbronnen & & & $-0,832$ & $-0,807$ & 0,741 \\
\hline Gezondheid op 20-jarige leeftijd * geboortejaar & & & & & 3,108 \\
\hline Scheiding ouders voor 18 jaar * geboortejaar & & & & & 0,370 \\
\hline Overlijden ouder voor 18 jaar * geboortejaar & & & & & $9,955^{*}$ \\
\hline Slachtoffer geweld voor 18 jaar * geboortejaar & & & & & 2,262 \\
\hline Cognitieve vaardigheden $*$ geboortejaar & & & & & 0,817 \\
\hline Opleidingsniveau * geboortejaar & & & & & 3,561 \\
\hline Ouderlijke economische hulpbronnen * geboortejaar & & & & & 2,578 \\
\hline Ouderlijke culturele hulpbronnen * geboortejaar & & & & & $-3,690$ \\
\hline Ouderlijke sociale hulpbronnen * geboortejaar & & & & & $-2,351$ \\
\hline $\mathrm{X}^{2}$ verandering & 215,105 & 244,220 & 218,562 & 260,597 & 278,256 \\
\hline Vrijheidsgraden & 16 & 12 & 14 & 26 & 44 \\
\hline
\end{tabular}

$\sim=p<0,1 ;{ }^{*}=p<0,05 ;{ }^{* *}=p<0,01 ;{ }^{* * *}=p<0,001$ (2-zijdig)

Bron: Familie-enquête Nederlandse Bevolking 2009 (eigen bewerking) 


\section{Summary}

\section{Intergenerational downward mobility in the Netherlands}

Several studies have shown that Dutch society has become more open in the last few decades as a result of increasing opportunities for upward social mobility. However, recently it has been observed that the likelihood of downward mobility has increased for the youngest (male) birth cohorts in the Netherlands. Despite this recent finding, social stratification research has paid little attention to test explanations of downward mobility. This article tries to fill in this knowledge gap by testing several theoretical perspectives that aim to explain intergenerational downward mobility of individuals. In addition, we examine historical trends to study whether the role of these explanations have changed over time. To test the predictive validity of these perspectives, we use data from the Family Survey Dutch Population 2009 $(N=1,423)$. The empirical results, first of all, indicate that individuals who were born in younger birth cohorts are more likely to experience downward mobility than individuals who were born in older cohorts. We thus replicate earlier findings for the Netherlands. Secondly, we find that cognitive skills and, especially, educational attainment provide individuals significant protection against downward mobility. These findings are mainly in line with the meritocratic perspective. Thirdly, the results reveal that the role of the presumed explanations of downward mobility has not changed over time. 